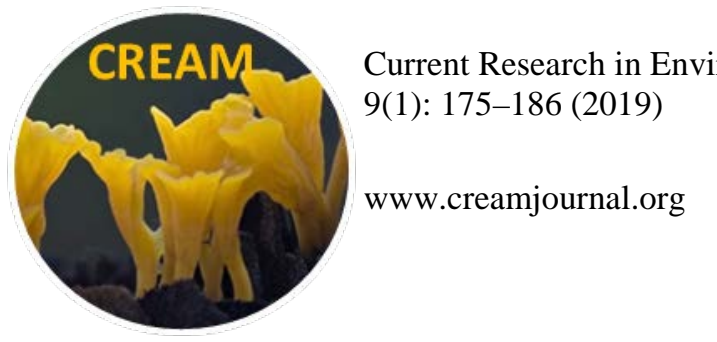

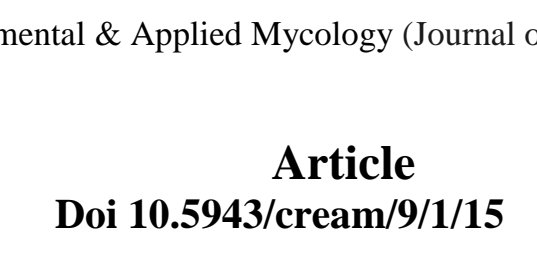

\title{
Aspergillus trisporus: A new Jani section species from Brazilian soil
}

\author{
Souza SC ${ }^{1}$, Pereira VM${ }^{1}$, Moreira $\mathrm{SI}^{2}$, Costa $\mathrm{SS}^{2}$, Moreira $\mathrm{GM}^{6}$, Mendes $\mathrm{WO}^{3}$, \\ Nery $\mathrm{EM}^{2}$, Alves $\mathrm{E}^{2}$, Chalfoun $\mathrm{SM}^{4}$, Moreira $\mathrm{FMS}^{5}$, Batista $\mathbf{L R}^{3 *}$ \\ ${ }^{1}$ Departamento de Biologia, Universidade Federal de Lavras, Lavras, MG 37200-000, Brazil \\ ${ }^{2}$ Departamento de Fitopatologia, Universidade Federal de Lavras, Lavras, MG 37200-000, Brazil \\ ${ }^{3}$ Departamento de Ciência dos Alimentos, Universidade Federal de Lavras, Lavras, MG 37200-000, Brazil \\ ${ }^{4}$ Empresa de Pesquisa Agropecuária de Minas Gerais, Lavras, MG 37200-000, Brazil \\ ${ }^{5}$ Departamento de Ciências do Solo, Universidade Federal de Lavras, Lavras, MG 37200-000, Brazil \\ ${ }^{6}$ Departamento de Fitopatologia, Universidade Federal de Viçosa, Viçosa, MG 36570-000, Brazil
}

Souza SC, Pereira VM, Moreira SI, Guimarães SSC, Moreira GM, Mendes WO, Nery EM, Alves E, Chalfoun SM, Moreira FMS, Batista LR 2019 - Aspergillus trisporus: A new Jani section species from Brazilian soil. Current Research in Environmental \& Applied Mycology (Journal of Fungal Biology) 9(1), 175-186, Doi 10.5943/cream/9/1/15

\begin{abstract}
Phenotypic characters and phylogenetic analyses based on ITS, $\beta$-tubulin (BenA) and the second largest subunit of RNA polymerase II (RPB2) gene sequences were applied to identify Aspergillus trisporus, a third member of the Aspergillus Jani section isolated from soil in the Ferriferous Quadrangle, Brazil. This new species has, as morphological markers, stipes of white conidiophores markedly smaller than the other species of the section and slow growth in all culture media evaluated. A. trisporus is phylogenetically and phenotypically more related to A. brevijanus, but it can be differentiated by non-growth at $37{ }^{\circ} \mathrm{C}$ and by the shorter stipes of the white conidiophores and predominantly clavated vesicles. This report contributes to the knowledge of Brazilian soils' fungal diversity, especially in poorly explored habitats such as the Ferriferous Quadrangle.
\end{abstract}

Key words - 1 new species - multilocus phylogeny - soil-borne fungi - taxonomy

\section{Introduction}

One of the oldest genera discovered, Aspergillus was first described almost 300 years ago by Micheli (1729). Since then, species of this genus have become increasingly well-known and much studied due to their beneficial characteristics, such as production of antibiotics, organic acids and enzymes. In addition, they are also commonly recognized for their negative impact on human activities, associated with food spoilage and mycotoxin production; some species are also described as pathogens of humans (Samson et al. 2014).

The genus Aspergillus is quite diverse, considered cosmopolitan and able to colonize an extensive variety of substrates, especially soils and decaying vegetation. This ability is related to its rapid growth over a wide temperature range $\left(6\right.$ to $\left.55^{\circ} \mathrm{C}\right)$, its high production of conidia, enzymes and other secondary metabolites (Klich 2002, Bennett 2010, Krijgsheld et al. 2013).

Advances in the analysis techniques for molecular biology and metabolites culminated in changes within the species classification of Aspergillus, and currently it is carried out by a 
polyphasic approach, based on colony characteristics, micromorphology, phylogeny and, in some cases, metabolite production (Samson et al. 2014, Tanney et al. 2014). Important modifications in the classification of Aspergillus can be mentioned, such as the division of the extensive family Trichocomaceae into three distinct families, Trichocomaceae, Aspergillaceae and Thermoascaceae, based on multigenic phylogeny (Houbraken \& Samson 2011). After this, the recent changes in the International Code of Nomenclature for Algae, Fungi and Plants (McNeill et al. 2012), mainly to support the principle of "one fungus: one name", led to discussions about whether to divide teleomorphs and anamorphs of Aspergillus into distinct genera or to keep them as a single genus. Thus, the currently accepted nomenclature is the maintenance of the name Aspergillus for the two states of life (Houbraken et al. 2014, Pitt \& Taylor 2014, Samson et al. 2014, Kocsubé et al. 2016). Finally, many studies have been carried out in order to reorganize the Aspergillus subgenera and sections based on phylogeny. Examples of this are the species A. janus and A. brevijanus, previously classified in the Versicolores, Terrei and Flavipedes sections, but which now belong to the Jani section (Hubka et al. 2015, Jurjević et al. 2015).

The Jani section comprises two species to date often associated with soil in many countries (Hubka et al. 2015). The Aspergillus janus Raper \& Thom neotype strain was isolated from soils in Panama, and the Aspergillus brevijanus S.W. Peterson neotype strain, formerly known as Aspergillus janus var. brevis Raper \& Thom, was obtained from soils in Mexico (Raper \& Thom 1944, Peterson 2008). The first reports of A. janus and A. brevijanus were based only on morphological markers, but the more recent works demonstrated that both species represent monophyletic groups, strongly supported by phylogenetic data using DNA sequences of the ITS region of rDNA and partial sequences of BenA, calmodulin, and RPB2 genes (Peterson 2008, Hubka et al. 2012, 2015).

A strain with the typical morphological characters of the Jani section, but morphologically different from the two described species in this group, was isolated from collections made in soils of the Ferriferous Quadrangle, Brazil. This area is recognized for its mineral wealth and as a biodiversity hotspot, due to important deposits of iron and gold and its unique environment, which has a number of endemic species that face a risk of extinction. In this study we describe and illustrate this identified strain, based on multilocus phylogeny and morphological characterization, as a new species within the Jani section.

\section{Materials \& Methods}

\section{Fungal isolation}

Two strains were obtained from soil samples collected at a depth of $20 \mathrm{~cm}$ under cultivation of Eucalyptus sp. in the VALE Biodiversity Center (VALE S.A. Company) in the Ferriferous Quadrangle, Minas Gerais, Brazil. Isolations were carried out using the soil dilution plate $\left(10^{1}\right.$ to $10^{4}$ ) on Dichloran Glycerol Agar (DG18) and Dichloran Rose-Bengal Chloramphenicol Agar (DRBC) media. After fungal growth, the monoconidial purification of the strains were done on Malt Extract Agar (MEA) and the fungi were deposited in the Coleção de Culturas do Departamento de Ciências dos Alimentos (CCDCA) and in the Coleção Micológica de Lavras (CML) in the Plant Pathology Department (Table 1). Both collections are located at the Universidade Federal de Lavras - UFLA, Minas Gerais, Brazil.

\section{DNA extraction, PCR and Phylogenetic analyses}

The strains were grown on potato-dextrose-agar and the biomass was harvested into $1.5 \mathrm{~mL}$ centrifuge tube. The total DNA of the strains were extracted using CTAB method (Doyle \& Doyle 1987). Portions of the internal transcribed spacer region (ITS, ITS1 and ITS4, White et al. 1990), the second largest subunit of RNA polymerase II (RPB2, fRPB2-5F and fRPB2-7cR, Liu et al. 1999), $\beta$-tubulin (BenA, TUB2FD and TUB4RD, Aveskamp et al. 2009), and calmodulin (CaM, CMD5 and CMD6, Hong et al. 2005) were amplified using a GoTaq Colorless Master Mix (Promega) in T100 Thermal Cycler (Bio-Rad). Cycling conditions for ITS RPB2 and CaM were 
according to Visagie et al. (2014) and for BenA were: $94 \mathrm{C}$ for $2 \mathrm{~min}, 40$ cycles of $94 \mathrm{C}$ for $30 \mathrm{~s}, 54$ $\mathrm{C}$ for $30 \mathrm{~s}$ and $72 \mathrm{C}$ for $40 \mathrm{~s}$, and a final extension at $72 \mathrm{C}$ for $4 \mathrm{~min}$. Gene regions were sequenced on a 3500 XL (Applied Biosystems) sequencer.

Bidirectional DNA sequences for each region were assembled by software SeqAssem (Hepperle 2004). The sequences were compared with those deposited in BLAST (Altschul et al. 1997), and additional sequences of type isolates of other species of Aspergillus were obtained from GenBank, NCBI (Table 1). The sequences were aligned by using ClustalW implemented in the MEGA X (Kumar et al. 2018). The alignments were deposited in TreeBASE (submission ID 21412, http://purl.org/phylo/treebase/phylows/study/TB2:S21412). Maximum parsimony (MP) and Maximum likelihood (ML) analyses were performed using MEGA X for each of the three gene regions and for the combined data sets. Clade stability was assessed with 1000 bootstrap replications (Alfaro et al. 2003). ML analysis was performed under the Tamura-Nei model of nucleotide substitution, with gamma rate heterogeneity and a proportion of invariant sites (TN93+G+I). Sequences of $A$. campestris (NRRL 13001) and A. candidus (NRRL 303), from the Candidi section, were selected as outgroup taxa. The DNA sequences generated in this study have been deposited in GenBank (Table 1).

\section{Morphological characterization}

The strains were grown at $25{ }^{\circ} \mathrm{C}$ in darkness on Czapek Yeast Extract Agar (CYA), Malt Extract Agar (MEA), Yeast Extract Sucrose Agar (YES) and Creatine Agar (CREA) for macromorphological observations. Plates with CYA were also incubated at 30 and $37{ }^{\circ} \mathrm{C}$ (Samson et al. 2014, Hubka et al. 2015). The cultures were grown in triplicate as a three-point inoculation on each medium in $90 \mathrm{~mm}$ diameter Petri dishes. Macro-morphology was described after 14 days of incubation when the colony color was fully expressed and all typical features were present (Hubka et al. 2015).

Microscopic observations were made using mounts in lactic acid from colonies grown on YES; alcohol 70\% was sprayed to remove air bubbles and excess of conidia. An inverted bright field Zeiss Axio Observer Z1 microscope with differential interference contrast (DIC) (Zen 2012 software) and a Nikon SMZ1500 stereoscope microscope (NIS Elements D3.2 software) were employed for micro-morphological examinations. When possible, the morphological structure measures were based on 30 units of each structure. To verify the occurrence of Hülle cells, subsequent examinations were done at 21 and 28 days of incubation. The images obtained were edited using Corel Draw X7.

Fragments of colonies grown on MEA $25{ }^{\circ} \mathrm{C}$ for 14 days were fixed in Karnovsky solution (pH 7.2), post-fixed with $1 \%$ osmium tetroxide solution and dehydrated in an acetone series for observation under Scanning Electron Microscopy (SEM) (Bozzola \& Russell 1999). Drying of the specimen was performed on the Critical Point apparatus (Bal-tec CPD 030 Balzers) followed by gold coating on Sputter Coater evaporator (Bal-tec SCD 050 Balzers). The acquisition of the images was performed with the Zeiss LEO EVO 40 XVP MEV in the UFLA Electronic Microscopy and Ultrastructural Analysis Laboratory, using Smart Sem software, at $20 \mathrm{Kv}$ and a working distance of $6 \mathrm{~mm}$. The images acquired were edited using Corel Draw X7.

\section{Results}

\section{Phylogenetic analyses}

Sequences from fragments of RPB2, BenA, ITS, and CaM were compared with sequences of type isolates of other species from Aspergillus subgroups in GenBank (Hubka et al. 2015). The aligned RPB2 sequences consisted of 1014 bp (353 variable sites of which 326 were phylogenetically informative), BenA of 610 bp (333/294), ITS of 477 bp (96 / 84), and CaM of 633bp (348/302). There were no conflicts among the topologies obtained using ML and MP, once the ML tree is shown in Fig. 1. In the phylogenetic analyses, a strongly supported clade was formed 
only with strains CCDCA FI15 and CCDCA 11948 within the Jani section, distinct from other species in this section, and it has A. brevijanus as sister species (Fig. 1).

Based on phylogenetic and morphological analysis the strains CCDCA FI15 and CCDCA 11948 were described as Aspergillus trisporus sp. nov.

Table 1 Aspergillus isolates and reference sequences of ITS, RPB2, BenA and CaM regions used in the phylogenetic analyses.

\begin{tabular}{|c|c|c|c|c|c|c|c|}
\hline \multirow[t]{2}{*}{ Species } & \multirow[t]{2}{*}{ Code(s)* } & \multirow[t]{2}{*}{ Origin } & \multirow[t]{2}{*}{ Reference } & \multicolumn{4}{|c|}{ GenBank Accession Number } \\
\hline & & & & ITS & RPB2 & BenA & CaM \\
\hline $\begin{array}{l}\text { A. trisporus sp. } \\
\text { nov. }\end{array}$ & $\begin{array}{l}\text { CCDCA FI 15/ } \\
\text { CML3603 }\end{array}$ & Soil, Brazil & This work & MF616388 & MF616389 & MF616387 & MN013146 \\
\hline $\begin{array}{l}\text { A. trisporus sp. } \\
\text { nov. }\end{array}$ & CCDCA 11948 & Soil, Brazil & This work & MK995631 & MN013143 & MN013144 & MN013145 \\
\hline A. ardalensis & CCF 4031 & Soil, Spain & Hubka et al. 2015 & FR733808 & HG916704 & HG916683 & HG916725 \\
\hline A. flavipes & NRRL 302 & $\begin{array}{l}\text { Bainier's culture of } \\
\text { Sterigmatocystus flavipes, France }\end{array}$ & $\begin{array}{l}\text { Thom \& Church } \\
1926\end{array}$ & EF669591 & EF669633 & EU014085 & EF669549 \\
\hline A. iizukae & NRRL 3750 & Soil, Japan & Sugiyama 1967 & EF669597 & EF669639 & EU014086 & EF669555 \\
\hline A. mangaliensis & CCF 4698 & Soil, Romania & Hubka et al. 2015 & HG915902 & HG916716 & HG916695 & HG916738 \\
\hline A. frequens & NRRL 4578 & Soil, Haiti & Hubka et al. 2015 & EF669602 & EF669644 & EU014082 & EF669560 \\
\hline A. neoflavipes & NRRL 5504 & $\begin{array}{l}\text { Cellulosic material buried in } \\
\text { forest soil, Thailand }\end{array}$ & Hubka et al. 2015 & EF669614 & EF669656 & EU014084 & EF669572 \\
\hline A. spelaeus & CCF 4425 & Cave sediment, Spain & Hubka et al. 2015 & HG915905 & HG916719 & HG916698 & HG916741 \\
\hline A. polyporicola & NRRL 58570 & $\begin{array}{l}\text { Basidioma of Earliella scabrosa, } \\
\text { USA }\end{array}$ & Hubka et al. 2015 & EF669595 & EF669637 & EU014088 & LM644252 \\
\hline A. movilensis & CCF 4410 & Soil, Romania & Hubka et al. 2015 & HG915904 & HG916718 & HG916697 & HG916740 \\
\hline A. luppii & NRRL 6326 & Natural truffle soil, France & Hubka et al. 2015 & EF669617 & EF669659 & EU014079 & EF669575 \\
\hline A. neoniveus & NRRL 5299 & Forest soil, Thailand & Samson et al. 2011 & NR137474 & EF669654 & EU014098 & EF669570 \\
\hline A. ambiguus & NRRL 4737 & Savannah soil, Somalia & Sappa 1955 & NR135400 & EF669648 & EF669534 & EF669564 \\
\hline A. microcysticus & NRRL 4749 & Savannah soil, Somalia & Sappa 1955 & NR135401 & EF669649 & EF669515 & EF669565 \\
\hline A. allahabadii & NRRL 4539 & Soil, India & $\begin{array}{l}\text { Mehrotra \& } \\
\text { Agnihotri } 1962\end{array}$ & NR135399 & EF669643 & EF669531 & EF669559 \\
\hline A. carneus & NRRL 527 & Culture contaminant, USA & Blochwitz 1933 & NR135402 & EF669653 & EF669529 & EF669569 \\
\hline A. neoindicus & NRRL 6134 & Soil, India & Samson et al. 2011 & NR131296 & EF669658 & EF669532 & EF669574 \\
\hline A. aureoterreus & NRRL 1923 & Wheat flour, India & Samson et al. 2011 & EF669580 & EF669622 & EF669524 & EF669538 \\
\hline A. alabamensis & NRRL 29810 & Soil, USA & Balajee et al. 2009 & EF669589 & EF669631 & EF669522 & EF669547 \\
\hline A. terreus & NRRL 255 & Soil, USA & $\begin{array}{l}\text { Thom \& Church } \\
1926\end{array}$ & EF669586 & EF669628 & EF669519 & EF669544 \\
\hline A. pseudoterreus & NRRL 4017 & Soil, Argentina & Samson et al. 2011 & NR137472 & EF669640 & EF669523 & EF669556 \\
\hline
\end{tabular}


Table 1 Continued.

\begin{tabular}{|c|c|c|c|c|c|c|c|}
\hline \multirow[t]{2}{*}{ Species } & \multirow[t]{2}{*}{ Code(s)* } & \multirow[t]{2}{*}{ Origin } & \multirow[t]{2}{*}{ Reference } & \multicolumn{4}{|c|}{ GenBank Accession Number } \\
\hline & & & & ITS & RPB2 & BenA & CaM \\
\hline A. brevijanus & NRRL 1935 & Soil, Mexico & Hubka et al. 2015 & EF669582 & EF669624 & EU014078 & EF669540 \\
\hline A. janus & NRRL 1787 & Soil, Panama & Hubka et al. 2015 & NR131295 & EF669620 & EU014076 & EF669536 \\
\hline A. campestris & NRRL 13001 & Soil, USA & Christensen 1982 & EF669577 & EF669619 & EU014091 & EF669535 \\
\hline A candidus & NRRL 303 & Unknown & Link 1809 & EF669592 & EF669634 & EU014089 & EF669550 \\
\hline
\end{tabular}

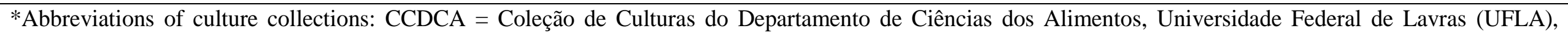

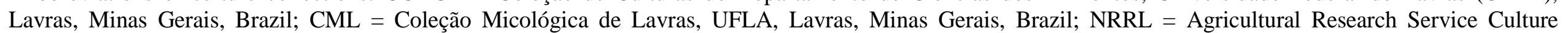

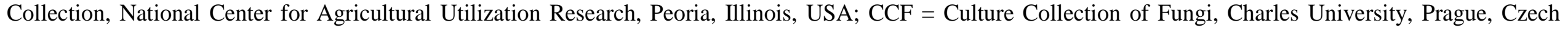
Republic.

\section{Taxonomy}

Aspergillus trisporus Souza, Pereira, Moreira \& Batista, sp. nov.

Index Fungorum number: IF 556635; Facesoffungi number: FoF 06279; MycoBank number: MB822378

Etymology - The epithet 'trisporus' refers to the three distinct conidia produced by the species.

Holotype - CCDCA FI15.

Asexual morph Conidiophores in three different types. Conidiophore in green heads radiate, biseriate, stipes uncolored to pale brown, smoothwalled, usually non-septate, 84-138 $\mu \mathrm{m}(\bar{x}=97 \pm 12) \mu \mathrm{m}(\mathrm{n}=25) \times 4-8 \mu \mathrm{m}(\bar{x}=6 \pm 0.6) \mu \mathrm{m}(\mathrm{n}=25)$. Vesicles pyriform to subclavate, 9-12 $\mu \mathrm{m}(\bar{x}=10 \pm 1)$ $\mu \mathrm{m}(\mathrm{n}=28)$ long and 5-8 $\mu \mathrm{m}(\bar{x}=6 \pm 0.7)(\mathrm{n}=28)$ wide. Metulae 5-9 $\mu \mathrm{m}(\bar{x}=7 \pm 0.8)(\mathrm{n}=29)$ long. Phialides 5-7 $\mu \mathrm{m}(\bar{x}=6 \pm 0.6)(\mathrm{n}=30)$ long. Conidia green, markedly echinulate and globose to subglobose, $3-4.3(\bar{x}=3.6 \pm 0.5) \mu \mathrm{m}$ diam. (without echinules). Conidiophore in white heads radiate, biseriate, stipes uncolored, smooth walled, usually non-septate, 325-740 $\mu \mathrm{m}(\bar{x}=514 \pm 114)(\mathrm{n}=24) \times 5-9 \mu \mathrm{m}(\bar{x}=7 \pm 1)$ (n=24). Vesicles clavate, 19-25 $\mu \mathrm{m}(\bar{x}=23 \pm 1.9)(\mathrm{n}=17)$ long and $13-20 \mu \mathrm{m}(\bar{x}=16 \pm 1.9)(\mathrm{n}=17)$ wide. Metulae 6-10 $\mu \mathrm{m}(\bar{x}=8 \pm 0.8)(\mathrm{n}=30)$ long. Phialides 5-8 $\mu \mathrm{m}(\bar{x}=6 \pm 0.8)(\mathrm{n}=30)$ long. Conidia hyaline, smooth and globose to subglobose, elliptical or ovoid, 2.2-3.8 $\mu \mathrm{m}(\bar{x}=2.7 \pm 0.5)$ ( $\mathrm{n}=25)$ diam. Conidiophore micro- to semimacronematous hyaline. Conidia hyaline, globose to subglobose, $3.3-5 \mu \mathrm{m}(\bar{x}=4.2 \pm 0.5)(\mathrm{n}=30)$ diam. Sexual morph not observed. Hülle cells were not present.

Culture characteristics - Colonies on CYA at $25^{\circ} \mathrm{C}$ reach $22-27 \mathrm{~mm}$ diameter in $14 \mathrm{~d}$ (Fig. 2A), floccose to granular, raised, wrinkled, irregular margin, sporulation greyish green, surface white to yellowish, white segments in margin, white and gray sterile mycelium in the colony center, reverse brownish. On CYA at $30{ }^{\circ} \mathrm{C}$ colonies attain 25-33 mm diameter (Fig. 2B), moderately raised, irregularly wrinkled, velutinous, light gray bluish coloration, with a lower field dark green and point white mycelium masses, reverse light brown. Colonies on CREA attain 17-21 mm diameter (Fig. 2C), floccose, white coloration, no acid production. On YES colonies reaching 24-27 mm diameter (Fig. 2D), raised, velutinous, greyish-dark green and white sporulation near the margin, white and gray sterile mycelium in the colony center, reverse light brownish in center and dark green and pale 
near the margin. Colonies on MEA attain 18-21 mm diameter (Fig. 2E), flat, low, velutinous, irregular margin, green sporulation near the margin and white gray covering the colony, mycelium in margin white to yellowish pale, reverse light brown. No growth on CYA at $37^{\circ} \mathrm{C}$. On YES two different growing lines of sporulation were observed, green and white (Fig. 2F, G). The white conidiophores were taller than the green one (Fig. 2H, I).
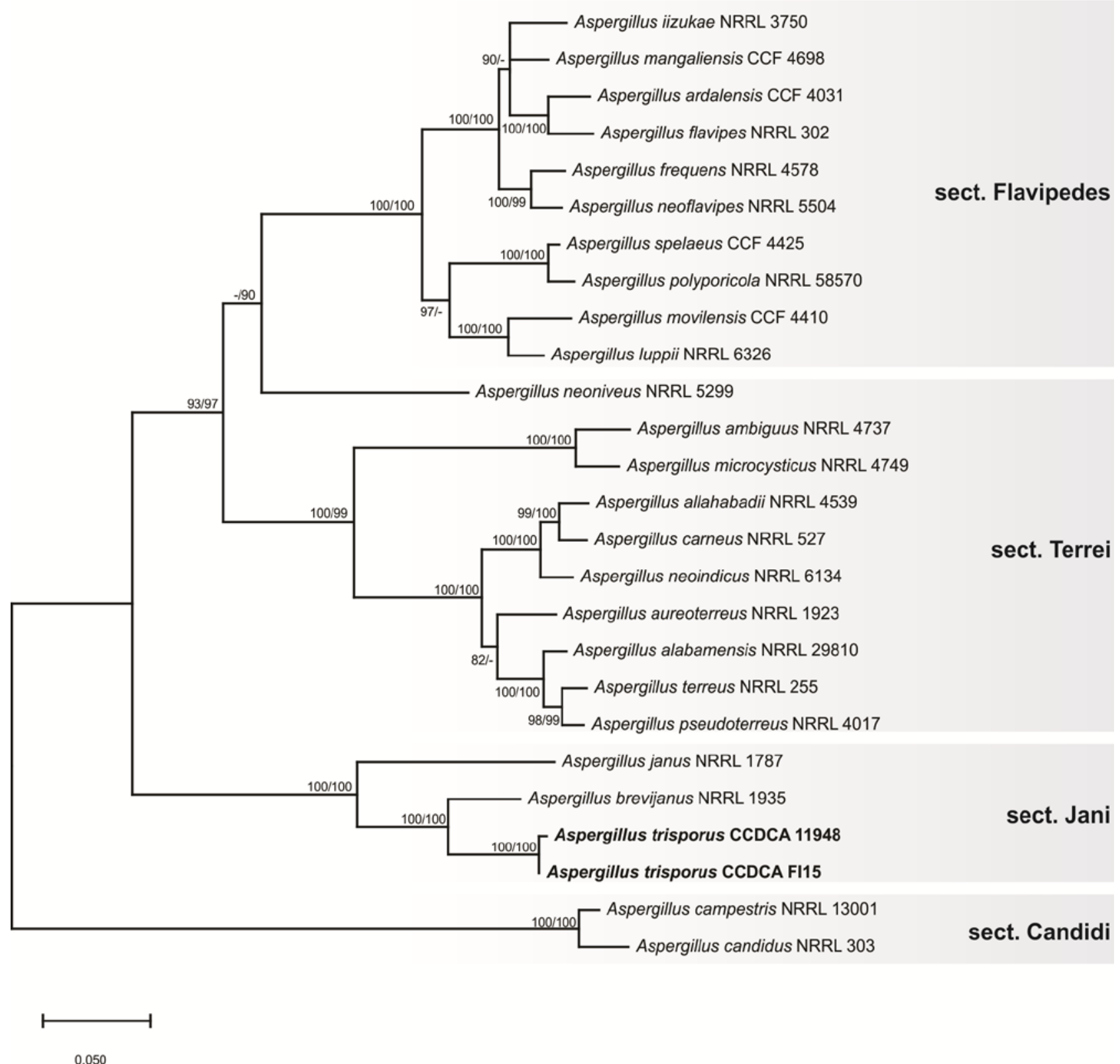

Fig. 1 - Maximum likelihood phylogenetic tree inferred from combined RPB2, BenA, ITS and CaM sequences showing the phylogenetic relationships of strain CCDCA FI15 and CCDCA 11948 with species of Aspergillus. The TN93 model of nucleotide substitution, with gamma rate heterogeneity and a proportion of invariant sites, was used as the model for nucleotide substitution. ML/MP bootstrap values $>70 \%$ are in the nodes. This tree is rooted with A. campestris (NRRL 13001) and A. candidus (NRRL 303). Abbreviations of culture collections: CCDCA= Coleção de Culturas do Departamento de Ciências dos Alimentos, Universidade Federal de Lavras, Lavras, Minas Gerais, Brazil; NRRL = Agricultural Research Service Culture Collection, National Center for Agricultural Utilization Research, Peoria Illinois, USA; CCF = Culture Collection of Fungi, Charles University, Prague, Czech Republic. 
Material examined - Brazil, Minas Gerais State, Sabará, Ferriferous Quadrangle soils, on soil, February 2014, Vanessa M. Pereira (Holotype CCDCAFI 15, CML 3603 - ex-type culture).

Notes - Aspergillus trisporus differs morphologically from A. janus and A. brevijanus in its shorter stipes of the white conidiophores and predominantly clavated vesicles. Shorter green conidiophores and the absence of Hülle cells differentiate it from A. janus, and no growth on CYA at $37{ }^{\circ} \mathrm{C}$ distinguishes it from $A$. brevijanus. The macro and microscopic characteristics of $A$. trisporus compared to the characteristics of $A$. janus and A. brevijanus are shown in Table 2. This new species differs from its closest phylogenetic species, $A$. brevijanus and $A$. janus, by $\mathrm{ML}$ and MP analyses, based on alignments of the concatenate sequences of ITS (MF616388), RPB2 (MF616389), BenA (MF616387), CaM (MN013146) and deposited in TreeBASE (S21412).

\section{Discussion}

Aspergillus trisporus nov. sp. belongs to the Jani Aspergillus section, which is composed of two other species, A. janus and A. brevijanus. Aspergillus trisporus presented typical characteristics of the section (Raper \& Thom 1944, Hubka et al. 2015), with green and white sporulation and grey and white sterile mycelia on CYA, YES and MEA media incubated at $25{ }^{\circ} \mathrm{C}$. Besides, it exhibits the typical conidiogenesis of the Jani section (Hubka et al. 2015), with at least three types of conidiophores: short biseriate conidiophores producing green echinulated conidia; long biseriate conidiophores with white and smooth conidia; and micro- to semi-macronematous conidiophores producing white and smooth accessory conidia (Fig. 2). This species differs phylogenetically from A. janus and A. brevijanus, with more proximity to A. brevijanus (Fig. 1). This closer kinship level can also be observed when considering the morphological aspects, since it has more characteristics in common with $A$. brevijanus than $A$. janus. The presence of shorter green conidiophores and the absence of Hülle cells are characteristics shared by A. trisporus and A. brevijanus, contrasting with A. janus, with longer green conidiophores and the presence of Hülle cells (Table 2). However, the white conidiophores of $A$. trisporus differ from A. brevijanus and A. janus, with shorter stipes and predominantly clavated vesicles (Table 2). In addition, $A$. trisporus and $A$. janus can be differentiated from $A$. brevijanus by the lack of ability to develop in CYA medium at $37^{\circ} \mathrm{C}$ (Table 2).

Other species of the Jani Aspergillus section were also reported associated with soils. Strains of A. brevijanus were isolated from soils in Mexico (Raper \& Thom 1944) and Turkey (Azaz \& Pekel 2002). On the other hand, isolates of A. janus were associated with soils in many countries, such as Brazil (in sand) (Gomes et al. 2008), Czech and Slovak Republics (Nováková et al. 2012), Egypt (in sand) (Migahed 2003), Pakistan (Mirza \& Bajwa 2005), Panama (Raper \& Thom 1944), Turkey (Asan 2004) and the USA (Hodges 1962). Besides that, strains of A. janus were found either in other environments, such as in blue pine seed in Pakistan (Farooq 2000), in a cave in Israel (Grishkan et al. 2004), in air and hospital air in India (Singh \& Singh 1999), in foodstuffs in Turkey (Asan 2004), in aeciospores of Cronartium comandrae in Canada (Powell 1971), in the digestive tract of Panstrongylus megistus in Brazil (Moraes et al. 2001), in a keyboard in Italy (Piccoli et al. 2001) and in carton material in the USA (Narciso \& Parish 1997).

The Ferriferous Quadrangle represents one of the most important mining regions in Brazil, containing large iron and gold mines (Azevedo et al. 2012). This region is also well known for its natural aspects and great beauty (Lamounier et al. 2011). It stands out, nationally, due to its unique environment, and it hosts many endemic species and some that are under risk of extinction, so it is considered a region of "extreme biological importance" (Costa 1998, Drummond et al. 2005). Thus, the description of $A$. trisporus contributes to the knowledge of the under-estimated fungal diversity, especially in Brazilian soils, and the species-rich Aspergillus genus, confirming the necessity of protecting natural habitats, such as those found in the Ferriferous Quadrangle. 


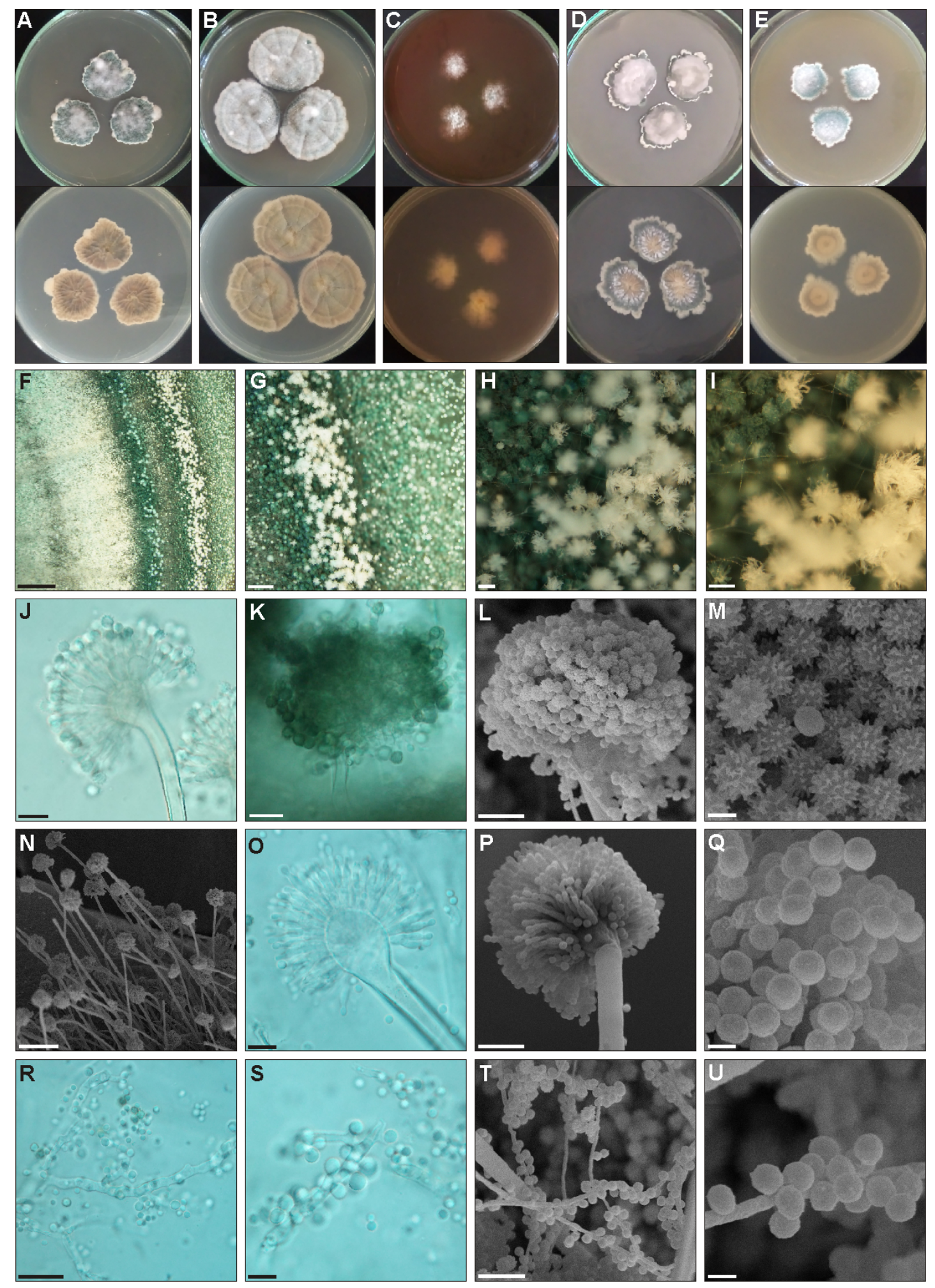

Fig. 2 - Aspergillus trisporus morphology. A-E Surface and reverse of colonies incubated 14 days in different culture media: (A) CYA $25^{\circ} \mathrm{C}$, (B) CYA $30^{\circ} \mathrm{C}$, (C) CREA $25^{\circ} \mathrm{C}$, (D) YES $25{ }^{\circ} \mathrm{C}$, (E) MEA $25{ }^{\circ} \mathrm{C}$. F-I Details of the colony growth in the YES medium observed using a stereomicroscope. J-U Micro-morphological characters of A. trisporus incubated at $25{ }^{\circ} \mathrm{C}$ on YES medium in darkness for 14 days: $(\mathrm{J}-\mathrm{M})$ green and echinulate sporulation in biseriate conidiophores, $(\mathrm{N}-\mathrm{Q})$ white sporulation and smooth walled conidia in long stipe biseriate conidiophores, (R-U) micro- to semi-macronematous conidiophores producing accessory conidia. J, K, O, R, S: bright field microcopy with DIC. L, M, N, P, Q, T, U: scanning electron microcopy. L, P, T: 3k× magnification. M, Q, U: 10k× magnification. Scale bars: F-G $=500 \mu \mathrm{m}, \mathrm{H}-\mathrm{I}, \mathrm{N}=100 \mu \mathrm{m}, \mathrm{J}-\mathrm{L}, \mathrm{O}-$ $\mathrm{P}, \mathrm{R}-\mathrm{T}=10 \mu \mathrm{m} . \mathrm{M}, \mathrm{Q}, \mathrm{U}=2 \mu \mathrm{m}$. 
Table 2 Aspergillus trisporus sp. nov. macro- and micro-morphology characteristics analyzed and compared with $A$. janus and $A$. brevijanus.

\begin{tabular}{|c|c|c|c|c|}
\hline & & A. trisporus sp. nov. & A. janus & A. brevijanus \\
\hline Colony & CYA $25^{\circ} \mathrm{C}$ & $22-27$ & $32-52$ & $28-44$ \\
\hline \multirow[t]{5}{*}{ Diameter (mm) } & CYA $30^{\circ} \mathrm{C}$ & $25-33$ & - & - \\
\hline & CYA $37^{\circ} \mathrm{C}$ & Not growth & Not growth & $10-15$ \\
\hline & CREA $25^{\circ} \mathrm{C}$ & $17-21$ & $20-36$ & $21-22$ \\
\hline & YES $25^{\circ} \mathrm{C}$ & $24-27$ & - & - \\
\hline & MEA $25^{\circ} \mathrm{C}$ & $18-21$ & $33-42$ & $28-35$ \\
\hline \multirow{9}{*}{$\begin{array}{l}\text { Green } \\
\text { conidiophore } \\
\text { structures } \\
(\mu \mathrm{m})^{*}\end{array}$} & Stipe length & $84-138$ & 500 & $55-120$ \\
\hline & Vesicle length & $9-12$ & $(4.5-) 9-16(-21)$ & $7.5-12$ \\
\hline & Vesicle shape & $\begin{array}{l}\text { Pyriform to } \\
\text { subclavate }\end{array}$ & $\begin{array}{l}\text { Globose, pyriform or } \\
\text { spatulate }\end{array}$ & Pyriform \\
\hline & Metule length & $(5-) 7(-9)$ & (3-) 4.5-6 (-7.5) & $4-7.5$ \\
\hline & Phialide length & $5-7$ & (3-) 4-5.5 (-6.5) & $4.5-5.5$ \\
\hline & $\begin{array}{l}\text { Conidia } \\
\text { diameter }\end{array}$ & $(3-) 3.6(-4.3)$ & $2.5-3.4$ & $3.1-4$ \\
\hline & $\begin{array}{l}\text { Conidia } \\
\text { surface }\end{array}$ & Markedly echinulate & Markedly echinulate & Echinulate \\
\hline & Conidia shape & $\begin{array}{l}\text { Globose to } \\
\text { subglobose }\end{array}$ & $\begin{array}{l}\text { Globose to } \\
\text { subglobose }\end{array}$ & $\begin{array}{l}\text { Globose to } \\
\text { subglobose }\end{array}$ \\
\hline & Conidial heads & Radiate & $\begin{array}{l}\text { Radiate to short } \\
\text { columnar }\end{array}$ & Radiate \\
\hline \multirow{9}{*}{$\begin{array}{l}\text { White } \\
\text { conidiophore } \\
\text { structures } \\
(\mu \mathrm{m})^{*}\end{array}$} & Stipe length & $(325-) 514(-740)$ & +1000 & +1000 \\
\hline & Vesicle length & $(19-) 23(-25)$ & $(10-) 45(-75)$ & $9-20$ \\
\hline & Vesicle shape & Clavate & $\begin{array}{l}\text { Spatulate, clavate, } \\
\text { globose or pyriform }\end{array}$ & Pyriform \\
\hline & Metule length & $(6-) 8(-10)$ & $(4-) 6.5(-8)$ & $(5.5-) 7(-9)$ \\
\hline & Phialide length & $(5-) 6(-8)$ & $(4-) 6(-7)$ & $5-6.5$ \\
\hline & $\begin{array}{l}\text { Conidia } \\
\text { diameter }\end{array}$ & $(2.2-) 2.7(-3.8)$ & $2.1-3$ & $(2.2-)$ 2.5-3.1 (-3.4) \\
\hline & $\begin{array}{l}\text { Conidia } \\
\text { surface }\end{array}$ & Smooth & Smooth & Smooth \\
\hline & Conidia shape & $\begin{array}{l}\text { Globose, subglobose, } \\
\text { ovoid or elliptical }\end{array}$ & $\begin{array}{l}\text { Globose, subglobose, } \\
\text { or elliptical }\end{array}$ & $\begin{array}{l}\text { Globose, subglobose, } \\
\text { ovoid or elliptical }\end{array}$ \\
\hline & Conidial heads & Radiate & $\begin{array}{l}\text { Loosely radiate to } \\
\text { radiate }\end{array}$ & $\begin{array}{l}\text { Loosely radiate to } \\
\text { radiate }\end{array}$ \\
\hline \multirow{2}{*}{$\begin{array}{l}\text { Micro- to semi- } \\
\text { macronematous } \\
\text { conidiophore } \\
\text { structures } \\
(\mu \mathrm{m}) *\end{array}$} & $\begin{array}{l}\text { Conidia } \\
\text { diameter }\end{array}$ & $(3.3-) 4.2(-5)$ & $(3-) 4.5(-5.5)$ & $3-5$ \\
\hline & Conidia shape & $\begin{array}{l}\text { Globose to } \\
\text { subglobose }\end{array}$ & $\begin{array}{l}\text { Globose, subglobose, } \\
\text { elliptical or clavate }\end{array}$ & $\begin{array}{l}\text { Globose, subglobose, } \\
\text { elliptical or clavate }\end{array}$ \\
\hline $\begin{array}{l}\text { Hülle cell } \\
(\mu \mathrm{m}) *\end{array}$ & $\begin{array}{l}\text { Conidia } \\
\text { diameter }\end{array}$ & - & $5-15$ & - \\
\hline
\end{tabular}

Acknowledgements

The authors thank the National Council for Scientific and Technological Development (CNPq), Minas Gerais Research Funding Foundation (FAPEMIG), Coordination for the Improvement of Higher Education Personnel (CAPES) and the VALE S.A. Company for their financial support, the Electronic Microscopy and Ultrastructural Analysis Laboratory for the technical support. 


\section{References}

Alfaro ME, Zoller S, Lutzoni F. 2003 - Bayes or bootstrap? A simulation study comparing the performance of Bayesian Markov chain Monte Carlo sampling and bootstrapping in assessing phylogenetic confidence. Molecular Biology and Evolution 20, 255-266.

Altschul SF, Madden TL, Schäffer AA, Zhang J et al. 1997 - Gapped BLAST and PSI-BLAST: a new generation of protein database search programs. Nucleic Acids Res. 25, 3389-402.

Asan A. 2004 - Aspergillus, Penicillium, and related species reported from Turkey. Mycotaxon 89, 155-157.

Aveskamp MM, Verkley GJM, Gruyter J, Murace MA et al. 2009 - DNA phylogeny reveals polyphyly of Phoma section Peyronellaea and multiple taxonomic novelties. Mycologia 101, 363-382.

Azaz AD, Pekel O. 2002 - Comparison of soil fungi flora in burnt and unburnt forest soils in the vicinity of Karicak (Alanya, Turkey). Turkish Journal of Botany 26, 409-416.

Azevedo UR, Machado MMM, Castro PTA, Renger FE et al. 2012 - Geoparque Quadrilátero Ferrífero (MG). In: Schobbenhaus C, Silva CR. (Eds.) Geoparques do Brasil/Propostas v. 1. CPRM, Rio de Janeiro, pp. 183-220.

Balajee SA, Baddley JW, Peterson SW, Nickle D et al. 2009 - Aspergillus alabamensis, a new clinically relevant species in the section Terrei. Eukaryotic Cell 8, 713-722.

Bennett JW (Ed.). 2010 - An overview of the genus Aspergillus. Caister Academic.

Blochwitz A. 1933 - Die Gattung Aspergillus. Neue Species, Synonyme und Nachträge. Annales Mycologici 3, 73-83.

Bozzola JJ, Russell LD. 1999 - Electron microscopy. Jones and Bartlett, Boston.

Christensen M. 1982 - The Aspergillus ochraceus group: two new species from western soils and a synoptic key. Mycologia 74, 210-225.

Costa CMR. 1998 - Biodiversidade em Minas Gerais: Um atlas para sua conservação 1a Ed. Fundação Biodiversitas, Belo Horizonte.

Doyle JJ, Doyle JL. 1987 - A rapid DNA isolation procedure for small quantities of fresh leaf tissue. Phytochemical Bulletin 19, 11-15.

Drummond GM, Martins CS, Machado ABM, Sebaio FA, Antonini Y. 2005 - Biodiversidade em Minas Gerais: Um Atlas para sua Conservação. Fundação Biodiversitas, Belo Horizonte.

Farooq A. 2000 - Mycoflora associated with blue pine seed. The Pakistan Journal of Forestry 50, 25-31.

Gomes D, Cavalcanti M, Fernandes M, Lima D, Passavante J. 2008 - Filamentous fungi isolated from sand and water of "Bairro Novo" and "Casa Caiada" beaches, Olinda, Pernambuco, Brazil. Brazilian Journal of Biology 68, 577-582.

Grishkan I, Nevo E, Wasser SP. 2004 - Micromycetes from the saline arubotaim cave: Mount Sedom, the Dead Sea southwestern shore, Israel. Journal of Arid Environments 57, 431-443.

Hepperle D. 2004 - SeqAssem ${ }^{\odot}$ : A sequence analysis tool, contig assembler and trace data visualization tool for molecular sequences. http://www.sequentix.de (accessed 07 February 2017).

Hodges CS. 1962 - Fungi isolated from southern forest tree nursery soils. Mycologia 54, 221-229.

Hong SB, Go SJ, Shin HD, Frisvad JC, Samson RA. 2005 - Polyphasic taxonomy of Aspergillus fumigatus and related species. Mycologia 97:1316-1329.

Houbraken J, De Vries RP, Samson RA. 2014 - Modern taxonomy of biotechnologically important Aspergillus and Penicillium species. Advances in Applied Microbiology 86, 199-249.

Houbraken J, Samson RA. 2011 - Phylogeny of Penicillium and the segregation of Trichocomaceae into three families. Studies in Mycology 70:1-51.

Hubka V, Kubatova A, Mallatova N, Sedlacek P et al. 2012 - Rare and new etiological agents revealed among 178 clinical Aspergillus strains obtained from Czech patients and characterized by molecular sequencing. Medical Mycology 50, 601-610. 
Hubka V, Novakova A, Kolarik M, Jurjevic Z, Peterson SW. 2015 - Revision of Aspergillus section Flavipedes: seven new species and proposal of section Jani sect. nov. Mycologia 107, 169-208.

Jurjević Ž, Kubátová A, Kolarik M, Hubka V. 2015 - Taxonomy of Aspergillus section Petersonii sect. nov. encompassing indoor and soil-borne species with predominant tropical distribution. Plant Systematics and Evolution 301:2441-2462.

Klich MA. 2002 - Biogeography of Aspergillus species in soil and litter. Mycologia 94, 21-27.

Kocsubé S, Perrone G, Magistà D, Houbraken J et al. 2016 - Aspergillus is monophyletic: Evidence from multiple gene phylogenies and extrolites profiles. Studies in Mycology 85, 199-213.

Kumar S, Stecher G, Li M, Knyaz C, Tamura K. 2018 - MEGA X: Molecular Evolutionary Genetics Analysis across computing platforms. Molecular Biology and Evolution 35:15471549.

Krijgsheld P, Bleichrodt RJ, van Veluw GJ, Wang F et al. 2013 - Development in Aspergillus. Studies in Mycology 74, 1-29.

Lamounier WL, Carvalho VLM, Salgado AAR. 2011 - Serra do Gandarela: Possibilidade de Ampliação das Unidades de Conservação no Quadrilátero Ferrífero-MG. Revista do Departamento de Geografia - USP 22: 171-192.

Link HF. 1809 - Observationes in ordines plantarum naturales. Der Gesellschaft Naturforschender Freunde 3, 3-42.

Liu YJ, Whelen S, Hall BD. 1999 - Phylogenetic relationships among ascomycetes: evidence from an RNA polymerse II subunit. Molecular Biology and Evolution 16, 1799-1808.

McNeill J, Barrie FR, Buck WR, Demoulin V et al. 2012 - International Code of Nomenclature for algae, fungi, and plants (Melbourne Code). http://www.iapt-taxon.org/nomen/main.php (acessed 03 March 2017).

Mehrotra BS, Agnihotri VP. 1962 - Two New Species of Aspergillus from India. Mycologia 54, 400-406.

Micheli PA. 1729 - Nova Plantarum Genera. B. Paperninii, Florence.

Migahed FF. 2003 - Distribution of fungi in the sandy soil of Egyptian beaches. Mycobiology 31, $61-67$.

Mirza J, Bajwa R. 2005 - New records of Fungi Imperfecti from Pakistan. Research Bulletin - 1st Fungal Culture Bank of Pakistan 1, 1-15.

Moraes AML, de Figueiredo AR, Junqueira ACV, da Costa GL et al. 2001 - Fungal flora of the digestive tract of Panstrongylus megistus (Reduviidae) used for experimental xenodiagnosis of Trypanosoma (Schizotripanum) cruzi Chagas, 1909. Revista Iberoamericana de Micología 18, 79-82.

Narciso J, Parish M. 1997 - Endogenous mycoflora of gable - top carton paperboard used for packaging fruit juice. Journal of Food Science 62, 1223-1239.

Nováková A, Šimonovičvá A, Kubátová A. 2012 - List of cultivable microfungi recorded from soils, soil related substrates and underground environment of the Czech and Slovak Republics. Mycotaxon 119, 1-186.

Peterson SW. 2008 - Phylogenetic analysis of Aspergillus species using DNA sequences from four loci. Mycologia 100, 205-226.

Piccoli B, Assini R, Gambaro S, Pastoni F et al. 2001 - Microbiological pollution and ocular infection in CAD operators: an on-site investigation. Ergonomics 44, 658-667.

Pitt JI, Taylor JW. 2014 - Aspergillus, its sexual states and the new International Code of Nomenclature. Mycologia 106:1051-1062.

Powell J. 1971 - Fungi and bacteria associated with Cronartium comandrae on lodgepole pine in Alberta. Phytoprotection 52, 45-51.

Raper KB, Thom C. 1944 - New Aspergilli from Soil. Mycologia 36, 555-575.

Samson RA, Varga J, Frisvad JC. 2011 - Taxonomic studies on the Genus Aspergillus. Studies in Mycology 69, 1-97. 
Samson RA, Visagie CM, Houbraken J, Hong SB et al. 2014 - Phylogeny, identification and nomenclature of the genus Aspergillus. Studies in Mycology 78, 141-73.

Sappa F. 1955 - Nuove specie di Aspergillus dei terreni della savana spinosa somala. Allionia 2, 247-257.

Singh A, Singh AB. 1999 - Aspergillus spp. as an important occupational risk factor among susceptible individuals. Aerobiologia 15, 233-240.

Sugiyama J. 1967 - Mycoflora in core samples from stratigraphic drillings in middle Japan. The genus Aspergillus. Journal of the Faculty of Science University of Tokyo, Section III, Botany 9, 377-405.

Tanney JB, Varga J, Kocsubé S, Szigeti G et al. 2014 - Phylogeny, identification and nomenclature of the genus Aspergillus. Studies in Mycology 78, 141-173.

Thom C, Church MB. 1926 - The Aspergilli. Williams \& Wilkins, Baltimore.

Visagie CM, Houbraken J, Frisvad JC, Hong SB et al. 2014 - Identification and nomenclature of the genus Penicillium. Stud. Mycol. 78, 343-371.

White TJ, Bruns T, Lee S, Taylor JW. 1990 - Amplification and direct sequencing of fungal ribosomal RNA genes for phylogenetics. In: Innis MA, Gelfand DH, Sninsky JJ, White TJ (eds) PCR protocols: a guide to methods and applications. NewYork, USA. AcademicPress.pp.315-322. 